\title{
STUDI KOMPARATIF PELAKSANAAN PERADILAN ISLAM DI NEGARA MALAYSIA DAN SAUDI ARABIA
}

\author{
Yusrizal \\ Fakultas Hukum Universitas Malikussaleh \\ E-mail:yusrizal_unimal@yahoo.co.id
}

\begin{abstract}
The legal system in Malaysia State reflects the plural model which appears in English Malay Colony. Much of the area of life must be governed by a federal public body. The shariah Court in Malaysia known as the Shariah Court which is a judicial institution that speaks, and sentences to Muslims for civil and criminal misconduct according to the jurisdiction allocated to it. The Shariah Court has jurisdiction as stipulated by the Malaysian Constitution. While in Saudi Arabia Quran and Sunnah Rasulullah s.a.w is the Constitution of the State, and shariah as the basic law implemented by tribunals (courts) shariyah with ulama as Judges and counselors. The Saudi Arabia judiciary is formed based on Islamic shariah which is inseparable from the role of King Abdul Aziz bin Abdul Rahman as-Saud who plundered the territories.
\end{abstract}

Kata Kunci: Mahkamah, Malaysia, Peradilan Islam, Saudi Arabia

\section{A. Latar Belakang}

Badan-badan peradilan di negara-negara menunjukkan perbedaan dan variasi yang sangat besar. Sistem peradilan dan pengorganisasiannya di negaranegara sangat erat hubungannya dengan sejarah negara yang bersangkutan. Susunan organisasi kekuasaan kehakiman antara satu negara dengan negara lainnya tidak sama. Perbedaan susunan kekuasaan kehakiman juga terjadi karena bentuk negara, misalnya pada bentuk negara federasi dan negara kerajaan. Susunan kekuasaan kehakiman pada negara yang berbentuk federal tercermin pada susunan organisasi dan yurisdiksi badan peradilan, seperti di Malaysia, sedangkan susunan organisasi kekuasaan kehakiman pada bentuk negara kerajaan, tercermin dalam bentuk susunan organisasi kekuasaan kehakiman, seperti Saudi Arabia.

Malaysia merupakan kerajaan federal yang terdiri dari tiga belas negara bagian yang meliputi daerah Semenanjung Malaka, yakni: Johor, Malak, Pahang, 
Negeri Sembilan, Selangor, Perak, Trengganu, Kelantan, Penang, Kedah, dan Perlis yang terletak di Malaysia Barat dan Malaysia Timur yang terdiri Sabah dan Serawak yang terletak di Kalimantan Bagian Utara. Federasi ini terbentuk pada tanggal 16 September 1963. Kepala Negara Malaysia adalah seorang raja dengan gelar "Yang Dipertuan Agung". Pemerintahan berada di tangan Perdana Menteri yang berhak membentuk Kabinet.

Malaysia adalah sebuah negara dengan bendera nasional bergambar bulan sabit dan bintang, dengan konstitusi yang menyatakan Islam sebagai agama resmi, dengan Perdana Menteri yang memberi perioritas tertinggi untuk menyatukan kaum muslim, dengan pemerintahan yang semua menteri utamanya beragama Islam, dan dengan idologi nasional yang ditegaskan oleh pemerintah bahwa merupakan "tugas suci setiap warga negara untuk membela dan mendukung" konsitusi yang menjamin kedudukan istimewa bangsa Melayu, peranan Sultan, dan penetapan Islam sebagai agama resmi (John L. Esposito dan John O. Volt, 1999: 198). Sebagai hukum yang hidup yang inheren dalam kehidupan umat Islam, maka hukum Islam telah menjadi bagian dari kehidupan umat, sehingga hukum Islam tidak lagi dirasakan sebagai norma-norma hukum yang dipaksakan dari luar diri masing-masing pemeluknya (Sudirman Tebba, 1993: 13).

Berbeda dengan Malaysia, Saudi Arabia adalah negara yang mempunyai sistem pemerintahan yang berbeda dengan negara-negara muslim lainnya. Negara ini tidak dapat dikategorikan sebagai negara sipil, tetapi proses penegakan hukum di negara ini dapat berjalan dengan tertib meskipun tidak menggunakan sistem civil law. Saudi Arabia tidak mengenal pemisahan kekuasaan legislatif, eksekutif, dan yudikatif. Kekuasaan negara ini berjalan di bawah Raja secara harmonis dan selalu berpegang teguh pada syariat Islam, dan walaupun negara ini mengalami kemajuan atau moderenisasi, tetapi tetap berpegang teguh pada syariat Islam dan tetap menggunakan tradisi lama (Anonim, "Peradilan pada Kerajaan Saudi Arabia”, http://scarmakalah.blogspot.co.id., diakses tanggal 25 Juni 2017).

Saudi Arabia merupakan kerajaan monarki konstitusional yang walaupun secara formal belum memiliki undang-undang dasar tertulis, tetapi telah menyatakan dengan tegas bahwa kaidah-kaidah pokok yang terkandung dalam Alquran 
dan Sunnah merupakan Undang-undang Dasar Negara (Ahmad Muhammad Ibrahim, 1972: 80-81). Berangkat dari pendirian ini, maka Kerajaan Saudi Arabia berkewajiban menerapkan semua ketentuan-ketentuan syariat Islam dan secara khusus semua prinsip-prinsip yang berkaitan dengan demokrasi Islam, sehingga dalam tataran aplikasinya, negara ini kemudian diklaim sebagai negara Islam dalam makna yang hakiki (Muhammad Tahir Azhari, 1992: 161-164).

Kedua negara (Malaysia dan Saudi Arabia) merupakan negara yang samasama mengakui dan menerapkan prinsip-prinsip hukum Islam sebagai hukum yang hidup dalam masyarakat, tetapi bentuk negaranya berbeda, yang tentunya akan berpengaruh terhadap pelaksanaan peradilan pada kedua negara tersebut. Hal ini menarik untuk dikaji dan dianalisis melalui pendekatan perbandingan, yang menurut Sjahran Basah (1986: 8), dikatakan bahwa: "fungsi perbandingan adalah untuk menjelaskan baik persamaan-persamaan maupun perbedaan-perbedaan terhadap obyek-obyek atau obyek-obyek yang diselidiki tersebut diterangkan oleh perbandingan sebagai suatu metode baik secara deskriptif, secara analisis, maupun secara teori dan kemudian dievaluasi, sehingga dapat bersifat induktif-deduktif".

\section{B. Metode Penelitian}

Penelitian ini dikategorikan sebagai penelitian hukum normatif (legal reaserch), yaitu penelitian terhadap kaidah hukum positif dan asas hukum yang dilakukan dengan cara melakukan evaluasi terhadap kaidah-kaidah hukum (peraturan perundang-undangan) yang relevan (Bagir Manan, 1999: 4). Penelitian hukum normatif adalah penelitian yang mengkaji asas-asas dan kaidah hukum (Ronny Hanitijo Soemitro, 1990: 11-12). Arief Sidharta mengatakan penelitian hukum normatif adalah jenis penelitian yang lazim dilakukan dalam kegiatan pengembangan ilmu hukum yang di Barat biasa juga disebut dogmatika hukum (Bernard Arief Sidharta, 2011: 142). Sifat penelitian ini adalah penelitian deskriptif, Suatu penelitian deskriptif dimaksudkan untuk memberikan data yang seteliti mungkin tentang manusia, keadaan atau gejala-gejala lainnya (Soerjono Soekanto, 1986: 9-10). Deskriptif berarti bahwa analisis data bersifat deduktif berdasarkan teori atau konsep yang bersifat umum diaplikasikan untuk men- 
jelaskan seperangkat data atau menunjukkan komparasi/hubungan seperangkat data dengan seperangkat data lainnya (Bambang Sunggono, 1998: 38).

Data penelitian adalah data sekunder, yaitu data yang diperoleh dari kepustakaan, yang meliputi: bahan hukum primer, yaitu bahan-bahan hukum yang mengikat, bahan sekunder yaitu yang memberikan penjelasan mengenai bahan hukum primer, dan bahan hukum tersier, yaitu bahan yang memberikan petunjuk maupun penjelasan terhadap bahan hukum primer dan sekunder seperti kamus hukum dan kamus bahasa (Soerjono Soekanto dan Sri Mamudji, 2001: 13). Data yang terkumpul dianalisis dengan tehnik analisis yuridis kualitatif. Menurut Tengku Erwinsyahbana (2017: 188-189) bahwa disebut analisis yuridis kualitatif, karena yang dianalisis adalah informasi yang didapat dari peraturan perundangundang, serta tulisan-tulisan ilmiah dalam bidang hukum (yuridis).

\section{Hasil Penelitian dan Analisis}

\section{Lembaga peradilan sebagai penegak hukum}

Peradilan berasal dari kata adil yang mendapat imbuhan "pe" dan "an". Adil berarti menempatkan sesuatu pada tempatnya, dengan tambahan "pe" dan "an", berarti tempat atau lembaga yang menempatkan sesuatu pada tempat-nya. Istilah peradilan dalam Bahasa Arab digunakan kata qadha' jamaknya aqdhiya' yang berarti memutuskan perkara/perselisihan antara dua orang atau lebih berdasarkan hukum Allah (Shoim Najwa. http://shoimnj.blogspot.co.id., diakses tanggal 20 Juni 2017). Penegakan peradilan berarti memerintahkan kebaikan dan mencegah bahaya kezaliman, menyampaikan hak kepada yang punya, mencegah terjadinya kezaliman dan mengusahakan islah di antara manusia guna menyelamatkan dari kesewenang-wenangan (Basiq Djalil, 2012: 9). Menurut Hasbi AshShiddieqy (1994: 30), bahwa kata peradilan menurut istilah fiqh adalah:

a. lembaga hukum (tempat dimana seseorang mengajukan permohonan keadilan).

b. perkataan yang harus dituruti yang diucapkan oleh seseorang yang mempunyai wilayah hukum atau menerangkan hukum agama atas dasar harus mengikutinya. 
Badan peradilan merupakan suatu lembaga yang berwenang untuk menyelesaikan semua sengketa hukum sesuai dengan bidang tugasnya masingmasing, sebagaimana yang dikemukakan Scholten yang dikutip H. Rochmat Soemitro (1976: 4), dikatakan bahwa pengadilan merupakan sub-sumptie aparaat, yaitu suatu badan yang menetapkan peraturan umum yang abstrak yang terdapat dalam undang-undang pada kasus tertentu. Di Indonesia, badan peradilan yang menjalankan kekuasaan kehakiman adalah Mahkamah Agung, yang membawahi badan peradilan umum, badan peradilan agama, badan peradilan militer, dan badan peradilan tata usaha negara. Badan peradilan agama, badan peradilan militer, dan badan peradilan tata usaha negara merupakan peradilan khusus. Badan peradilan umum merupakan badan peradilan bagi rakyat pada umumnya, sedangkan badan peradilan khusus, memeriksa dan mengadili perkara di bidang hukum tertentu atau mengenai golongan rakyat tertentu (Bagir Manan, 1998: 33).

Menurut Oyo Sunaryo Mukhlas (2011: 7) dikatakan bahwa peradilan yang merupakan institusi masyarakat memiliki beberapa pilar yang bersifat integral, antara pilar yang satu dengan pilar yang lainnya tidak dapat dipisahkan. Pilar-pilar yang dimaksud, yaitu lembaga (badan) yang terorganisir berdasarkan kekuatan undang-undang, organ pelaksana sebagai penegak hukum (hakim), dan sarana hukum sebagai rujukan (hukum material).

Basiq Djalil (2006: 25), menjelaskan bahwa penyebutan peradilan khusus tidaklah dimaksudkan untuk mengistimewakan warga negara yang diadili atau mencari keadilan melalui lembaga peradilan, karena menurut Bagir Manan (1998: 10), bahwa hal penting dari kekuasaan kehakiman yang merdeka adalah untuk menjamin sikap tidak memihak, adil, jujur, atau netral (impartiality). Apabila kebebasan tidak dimiliki oleh kekuasan kehakiman, dapat dipastikan akan bersikap tidak netral, terutama apabila terjadi sengketa antar penguasa dan rakyat.

\section{Sistem peradilan Islam di Malaysia}

Pada dekade 80-an telah diupayakan perbaikan hukum Islam di berbagai negara bagian di Malaysia, dan konferensi nasional telah diadakan di Kedah untuk membicarakan hukum Islam, khususnya yang berkaitan dengan masalah hukum pidana, yang dalam konferensi diputuskan untuk membentuk sebuah komite yang 
terdiri dari ahli hukum Islam dan anggota bantuan hukum, yang kemudian dikirim ke berbagai negara Islam untuk mempelajari hukum Islam dan penerapannya.

Sebagai wujud perhatian pemerintah federal kepada hukum Islam, maka pada saat yang sama dibentuk beberapa komite yang bertujuan untuk menelaah struktur, yuridiksi, dan wewenang Pengadilan Syari'ah dan merekomendasikan pemberian wewenang dan kedudukan yang lebih besar kepada hakim Pengadilan Syaria'ah, mempertimbangkan suatu kitab hukum keluarga Islam yang baru guna mengantikan yang lama sebagai penyeragaman undang-undang di negara bagian.

Menurut Basiq Djalil (2006: 103-105), bahwa komite juga mempertimbangkan proposal adaptasi hukum acara pidana dan perdata bagi Pengadilan Syari'ah, dan sebagai hasilnya, beberapa undang-undang telah ditetapkan, yaitu:

a. Administrasi Hukum Islam.

1) UU Administrasi Pengadilan Kelantan, 1982.

2) UU Mahkamah Syari'ah Kedah, 1983.

3) UU Administrasi Hukum Islam Wilayah Federal, 1985.

4) Hukum Keluarga:

a) UU Hukum Keluarga Islam Kelantan, 1983.

b) UU Hukum Keluarga Islam Negeri Sembilan, 1983.

c) UU Hukum Keluarga Islam Malaka, 1983.

d) UU Hukum Keluarga Islam Selangor, 1984.

e) UU Hukum Keluarga Islam Perak ,1984.

f) UU Hukum Keluarga Islam Kedah, 1984.

g) UU Hukum Keluarga Islam Wilayah Federal, 1984.

h) UU Hukum Keluarga Islam Penang, 1985.

i) UU Hukum Keluarga Islam Trengganu, 1985.

b. Acara Pidana:

1) UU Acara Pidana Islam Kelantan,1983.

2) UU Hukum Acara Pidana Islam Wilayah Federal.

c. Acara Perdata.

1) UU Hukum Acara Perdata Islam Kelantan 1984.

2) UU Hukum Acara Perdata Islam Kedah, 1984. 
Pada dasarnya hukum Islam di Malaysia, ada yang menyangkut persoalan perdata dan ada yang menyangkut persoalan pidana (Fahim Abdullah bin Abdul Rahman, 1991: 96). Dalam bidang perdata meliputi: (a) pertunangan, nikah, cerai, membatalkan nikah atau perceraian; (b) memberi harta benda atau tuntutan terhadap harta akibat perkara nikah atau perceraian; (c) nafkah orang di bawah tanggungan, anak yang sah, penjagaan dan pemeliharaan anak; (d) pemberian harta wakaf; dan (e) perkara lain yang diberikan kuasa berdasarkan undangundang. Dalam persoalan pidana mengatur: (a) penganiayaan terhadap istri dan tidak patuh terhadap suami; (b) melakukan hubungan seks yang tidak normal; (c) penyalahgunaan minuman keras; (d) kesalahan terhadap anak angkat; dan (e) kesalahan-kesalahan lain yang diatur lebih jauh dalam undang-undang.

Beberapa masalah telah diatur dalam hukum Islam di Malaysia, tetapi hukum peninggalan Inggris tetap diberlakukan pada sebagian besar legislasi dan yudisprudensi. Undang-undang Hukum Perdata 1956 menyebutkan bahwa jika tidak didapatkan hukum tertulis di Malaysia, Pengadilan Perdata harus mengikuti hukum adat Inggris atau aturan lain yang sesuai. Dengan demikian, hukum Islam hanya berlaku pada wilayah yang terbatas, yaitu yang berhubungan dengan keluarga dan pelanggaran agama. Dalam hukum keluarga, pengadilan perdata tetap memiliki yuridiksi, seperti dalam kasus hak milik, warisan, serta pemeliharan anak, dan apabila terdapat pertentangan antara pengadilan perdata dan syari'ah, maka kewenangan peradilan perdata lebih diutamakan (Abdul Rahman Haji Abdullah, 1997: 151).

Federasi Malaysia adalah suatu negara yang mencantumkan dengan resmi Islam sebagai Agama Negara. Hal ini dijelaskan dalam Pasal 3 ayat (1) Konstitusi Malaysia yang menentuan bahwa: "Islam ialah agama bagi Persekutuan; tetapi bagi agama-agama lain boleh diamalkan dengan aman dan damai dimana-mana bahagian Persekutuan". Konsekuensi logis dari ketentuan itu, adanya hubungan antara Federasi Malaysia sebagai negara dengan agama Islam, sehingga Malaysia tidak dapat dinamakan negara sekuler.

Peraturan Malaysia memuat tentang petadbiran (pengaturan) agama Islam, dan dalam hubungan dengan pelaksanaan prinsip musyawarah sebagai suatu 
prinsip nomokrasi Islam, maka prinsip ini dilaksanakan dalam praktik pada Majelis Agama Islam, sebagai badan perundangan yang diberi fungsi untuk membuat peraturan yang berhubungan dengan pentadbiran tentang pengelolaan zakat, wakaf dan baitul mal (Ahmad Mohamed Ibrahim, 1985: 55). Dilihat dari sudut nomokrasi Islam, pencantuman agama Islam sebagai agama resmi Federasi Malaysia merupakan suatu faktor yang positif dan sangat menunjang proses Islamisasi di Federasi Malaysia.

Malaysia memiliki sistem federal yang membagi kekuasaan pemerintahan menjadi pemerintahan federal dan pemerintahan negara bagian. Pembagian kekuasaan ini tercantum dalam undang-undang dasar federal, dan walaupun undang-undang dasar menggunakan sistem federal, tetapi sistem ini berjalan dengan kekuasaan yang besar dari pemerintahan pusat. Beberapa kewenangan dari pemerintahan federal adalah urusan luar negeri, pertahanan, keamanan nasional, polisi, hukum perdata dan pidana sekaligus prosedur dan administrasi keadilan, kewarganegaraan, keuangan, perdagangan, perniagaan dan industri, perkapalan, navigasi dan perikanan, komunikasi dan transportasi, kinerja dan kekuasaan federal, pendidikan, kesehatan, ketenagakerjaan, dan keamanan sosial.

Beberapa kewenangan negara bagian adalah hal-hal yang berkaitan dengan praktik agama Islam dalam negara, hak kepemilikan tanah, kewajiban pengambilan tanah, izin pertambangan, pertanian dan eksploitasi hutan, pemerintahan kota, dan kerja publik demi kepentingan negara. Terdapat juga beberapa kekuasaan yang berlaku secara bersamaan, yaitu: sanitasi, pengaliran dan irigasi, keselamatan dari kebakaran, kependudukan dan kebudayaan, serta olah raga. Ketika hukum federal dan hukum negara bagian saling bertentangan maka hukum federal yang dianggap berlaku, karena konstitusi Malaysia mengatur kekuasaan federal lebih kuat dibanding dengan negara-negara bagiannya (Mohd. Saleh Abbas, 2006: 215).

Masing-masing negara bagian juga memiliki undang-undang dasar yang harus mencantumkan beberapa ketentuan undang-undang dasar federal. Hal ini juga menyatakan Malaysia sebagai negara federal, monarki konstitusi, dan demokrasi parlementer. Ketentuan ini juga menyatakan Islam sebagai agama 
negara tetapi dengan tetap menghormati kebebasan beragama. Undang-undang dasar ini juga menyediakan kerangka cabang-cabang pemerintahan eksekutif, parlemen, dan yudikatif.

Sistem hukum di Negara Malaysia mencerminkan model plural yang muncul di Inggris Melayu koloni. Sebagian besar wilayah kehidupan itu harus diatur oleh suatu badan umum hukum federal. Undang-undang Federal pada saat kemerdekaan terutama didasarkan pada model Inggris. Beberapa aspek dari kehidupan Muslim, bagaimanapun, itu harus diatur bukan oleh hukum federal, tetapi oleh negara Islam berbasis hukum disebut secara lokal sebagai Syari'ah hukum. Dalam konteks ini, negara-negara yang diizinkan untuk mendirikan sendiri negara sistem pengadilan Islam, yang dikenal secara lokal sebagai pengadilan syari'ah, untuk menerapkan hukum. Sebagai bekas jajahan Inggris, Malaysia tetap mempertahankan tradisi hukum kebiasaan Inggris. Tradisi ini berdiri di tengah-tengah sistem hukum Islam (yang dilaksanakan oleh Pengadilan Syari'ah) dan hukum adat berbagai kelompok penduduk asli (Melayu) yang ada di Malaysia.

Malaysia merupakan salah satu dari sekian banyak negara Coomonwealth Country atau negara-negara persemakmuran Inggris. Semua negara-negara persemakmuran mengadopsi sistem hukum Inggris yang biasa disebut dengan sistem hukum Anglo Saxon atau juga Common Law. Prinsip aturan hukum yang dipraktikkan di Malaysia secara umum mengikuti hukum administratif Inggris sebagaimana dikembangkan dalam pengadilan Malaysia, sehingga sistem pengadilan secara mendasar bersifat federal. Hukum federal maupun negara bagian dilaksanakan di pengadilan federal. Hanya Pengadilan Syari'ah yang terdapat pada negara bagian dan menggunakan sistem Hukum Islam, bersama dengan pengadilan pribumi di Sabah dan Sarawak, khususnya yang berurusan dengan hukum adat. Selain itu juga terdapat Sessions Courts (pengadilan sessi) dan Magistrate's Courts (Pengadilan Majistret). Pengadilan Tinggi dan tingkat pengadilan di bawahnya memiliki yurisdiksi dan kewenangan yang diatur oleh hukum federal, dan tidak memiliki yurisdiksi dalam segala hal yang berkaitan dengan yurisdiksi Pengadilan Syari'ah. 
Struktur kehakiman di Malaysia terdiri dari Mahkamah Persekutuan (Federal Court) dan di bawah itu Mahkamah Banding atau Mahkamah Rayuan (Appeal Court). Kemudian di bawah kedua Mahkamah tersebut Mahkamah Tinggi Malaya (High Court of Malaya), yang berada di Kuala Lumpur dan Mahkamah Tinggi Sabah dan Serawak (High Court of Sabah and Serawak), yang berada di tempat kedudukan oleh Raja (Yang Dipertuan Agung). Selanjutnya di bawah Mahkamah Tinggi tersebut ada Mahkamah Rendah (Session court), Mahkamah Mejistret dan Mahkamah Juvenile (Magistrate's Court/Juvenile Court), serta Mahkamah Penghulu, seperti dijelaskan oleh Jayum Ajawan (2006: 133), bahwa:

The present structure of the Malaysian Judiciary is presented in Appendix 2. It comprises at its apex the Federal Court and below that the Appeal Court. Below these are the High Court of Malaya and the High Court of Sabah and Sarawak. Together, these three courts formed the superior court. The subordinate court comprises the Sessions Court, the Magistrate Court and the Juvenile Court while at the lowest level is the Penghulu's Court.

Gambar 1:

Struktur Peradilan di Malaysia

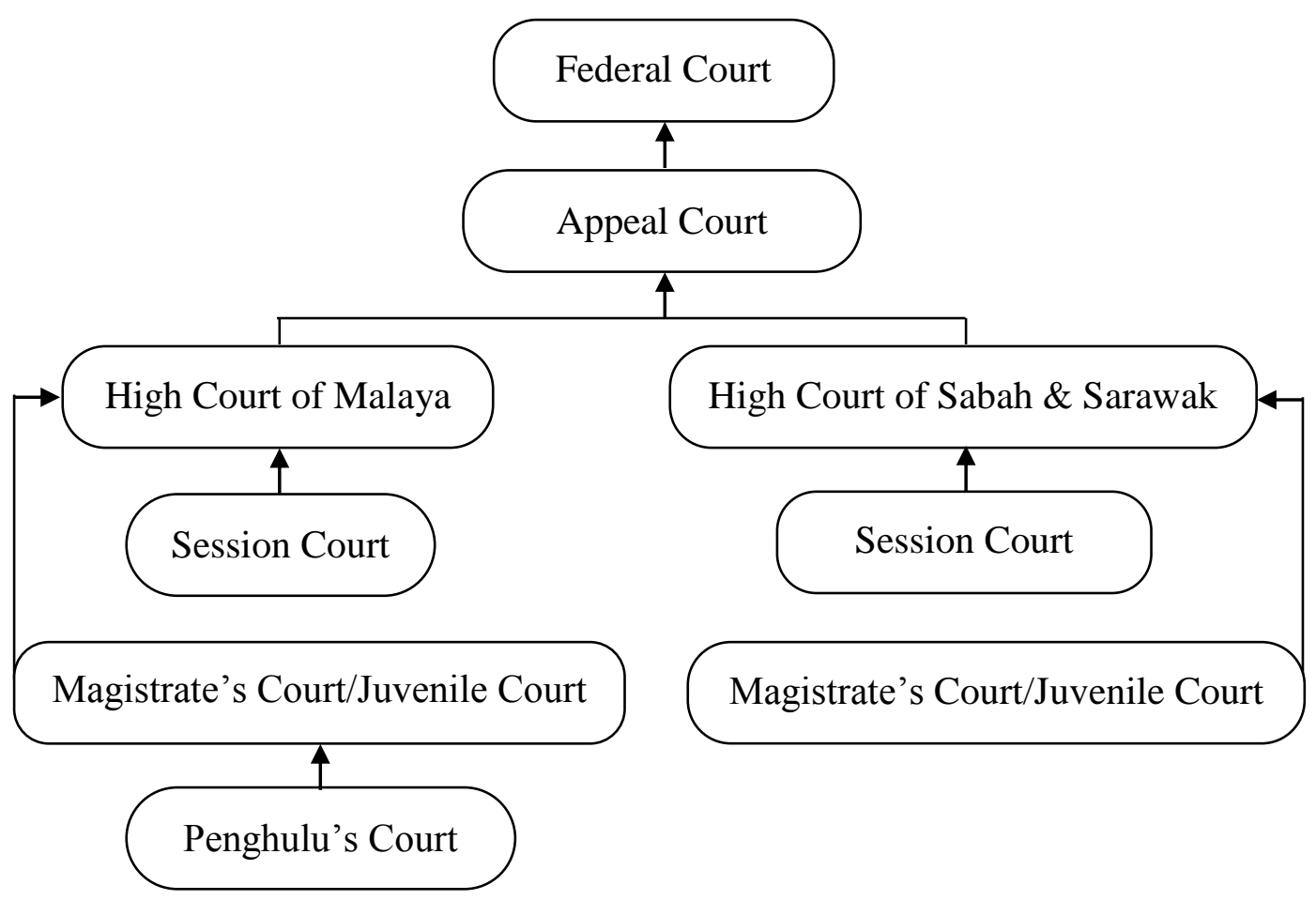


Lebih lanjut Ajawan (2006: 134-139), menjelaskan bahwa negara bagian Sabah dan Serawak juga dikenal Mahkamah Adat yang mengadili hukum adat, kebiasaan dan tradisi, sedangkan di tingkat negeri ada Mahkamah Syari'ah yang menangani perkara agama Islam yang terdiri dari Mahkamah Syari'ah Banding (Mahkamah Syari'ah Rayuan, Mahkamah Syari'ah Tinggi dan Mahkamah Syari'ah Rendah). Pelaksanaan kekuasaan pada kelima tingkat mahkamah, yaitu:

a. Mahkamah Mejistret, berwenang menangani tindak pidana Islam (Jinayah) dan Perdata (Sipil) seperti perampokan dan urusan rumah tangga. Mahkamah Mejistret terbagi dalam 2 (dua) tingkat, yaitu Mejistret Kelas I dan Mejistret Kelas II;

b. Mahkamah Rendah (Session Court), berwenang menangani kasus-kasus Pidana Islam (Jinayah) dan perdata, dan dalam kasus jinayah, kewenangan yang diberikan terhadap seseorang bukan merupakan hukuman mati;

c. Mahkamah Tinggi Malaya (High Court of Malaya) dan Mahkamah Tinggi Sabah dan Serawak (High Court of Sabah and Serawak) merupakan perwakilan pertama tingkat banding (rayuan). Dalam menangani kasus-kasus jinayah oleh mahkamah-mahkamah tinggi ini, sebelumnya harus dilalui oleh penyelidikan (inquiry) di tingkat Mahkamah Rendah;

d. Mahkamah Banding atau Mahkamah Rayuan (Appeal Court) mempunyai kewenangan untuk mendengar kasus-kasus jinayah dan perdata dari Mahkamah Tinggi dan kasus-kasus jinayah dari Mahkamah Rendah. Dalam masalah jinayah, Mahkamah Banding mempunyai kewenangan untuk mendengar dan memutuskan perkara-perkara yang diputuskan Mahkamah Tinggi dalam kasus perdata;

e. Mahkamah Persekutuan (Federal Court) merupakan mahkamah tertinggi dan terakhir dimana wilayah kekuasaan Mahkamah Persekutuan, yang menurut Mohd. Salleh Abbas (2006: 133), yaitu:

1) Menguji undang-undang yang dibuat oleh parlimen maupun Dewan Negeri di luar kewenangannya;

2) Menyelesaikan konflik antara federal dengan negara bagian atau antara negara bagian dengan negara bagian; 
3) Menjawab atau menyelesaikan permasalahan konstitusi yang timbul dalam mahkamah lainnya;

4) Memberi pendapat mengenai konstitusi jika diminta oleh Raja.

Keberadaan Mahkamah Persekutuan mengikat semua mahkamah di bawahnya dalam kasus perdata dan jinayah (Ahmad Ibrahim dan Ahilemah Joned, 2005: 182).

Terdapat 2 (dua) pengadilan tinggi di Malaysia, yaitu satu di Semenanjung Malaysia, yang dikenal sebagai Pengadilan Tinggi di Malaya, dan yang lain di Malaysia Timur, yang dikenal sebagai Pengadilan Tinggi di Sabah dan Sarawak. Dengan pengecualian segala persoalan dalam yurisdiksi pengadilan Syari'ah, pengadilan ini memiliki yurisdiksi murni tidak terbatas pada wilayahnya, yang juga dapat menerima pengajuan banding dari Session Courts dan Magistrate's Courts. Pengadilan Tinggi di Malaysia kedudukannya untuk memeriksa perkara tingkat pertama dan juga sebagai tingkat banding bagi Session Courts dan Magistrate's Courts. Beberapa Pengadilan Banding di antaranya Pengadilan Banding Malaysia (Mahkamah Rayuan) dan Pengadilan Federal (Mahkamah Persekutuan). Kewenangan Pengadilan Banding adalah untuk memeriksa pengajuan banding pengadilan tinggi dan memiliki yurisdiksi lain sebagaimana diatur hukum federal.

Pengadilan Federal terdiri dari ketua peradilan pengadilan federal, presiden pengadilan banding, kepala hakim pengadilan tinggi, dan 7 hakim lainnya yang ditunjuk raja di bawah nasehat ketua peradilan Pengadilan Federal. Pengadilan Federal memiliki yurisdiksi dalam menetukan keabsahan sebuah hukum dengan pertimbangan hal ini berkaitan dengan persoalan di luar kewenangan parlemen dan legislasi negara bagian dalam membuat hukum.

Pengadilan Syari'ah adalah pengadilan di negara bagian yang agak terpisah dari pengadilan federal, yang tidak memiliki yurisdiksi apapun dalam Pengadilan Syari'ah. Dengan kata lain bahwa pengadilan federal sama sekali tidak memiliki yurisdiksi dalam perkara-perkara syari'ah yang menjadi kewenangan Pengadilan Syari'ah. Pengadilan ini memiliki yurisdiksi atas kaum muslim berkaitan dengan hukum perseorangan dan keluarga misalnya pertunangan, 
pernikahan, perceraian, perwalian, adopsi, legitimitasi, suksesi, beserta sedekah dan wakaf. Yurisdiksi pada hukum pidana terbatas pada apa yang sudah ada pada pengadilan federal dan terbatas hanya pada kaum muslim yang melanggar hukum Syari'ah dimana pelaku dapat dikenai hukuman maksimal 3 tahun penjara, dan denda sebesar 5.000 Ringgit, hukum cambuk maksimal 6 kali atau gabungan atas dua atau lebih.

Sebagai contoh, bahwa di Tawau, Sabah, Malaysia terdapat 3 sistem kekuasaan kehakiman, yaitu: (a) Mahkamah Sipil (Peradilan Umum); (b) Mahkamah Syari'ah (Peradilan Agama); dan (c) Mahkamah Anak Negeri (Pengadilan Adat). Mahkamah Sipil adalah pengadilan yang berlaku untuk seluruh penduduk Sabah, baik Islam maupun bukan Islam, seperti Peradilan Umum di Indonesia. Mahkamah Sipil diketuai oleh Ketua Hakim Negara yang pelantikannya dilakukan oleh Kerajaan Persekutuan/Suruhanjaya Kehakiman (Pemerintah Malaysia), dan gajinya untuk majistret ke bawah, termasuk penjawat awan dibayarkan oleh Kerajaan (Pemerintah), sedangkan Hakim Mahkamah Tinggi dibayarkan melalui Kumpulan Wang Disatukan. Mahkamah Syari'ah adalah pengadilan khusus orang Islam, seperti Peradilan Agama di Indonesia. Mahkamah Syari'ah diketuai oleh Ketua Hakim Syar'i Negeri Sabah, yang pelantikannya dilakukan oleh Kerajaan Persekutuan/Kerajaan Negeri setelah mendapat tauliah dari Yang Dipertuan Negeri Sabah, sedangkan gajinya untuk penjawat awam sepenuhnya dibayarkan oleh Kerajaan (Pemerintah), sedangkan Pengadilan Anak Negeri adalah pengadilan yang berlaku di Negeri Sabah saja dan berkuat kuasa (berwenang) khusus untuk orang bukan Islam saja yang berstatus Anak Negeri Sabah, yakni suku-suku asli yang ada di Sabah, seperti Kadazan, dan umumnya beragama Nasrani. Pengadilan Anak Negeri ini adalah seperti Pengadilan Adat di Indonesia. Pengadilan Anak Negeri diketuai oleh Ketua Daerah yang pelantikannya dilakukan oleh Kerajaan Negeri Sabah, dan tidak menerima gaji, tapi hanya menerima elaun (semacam honor) dari Kerajaan Negeri Sabah.

Tiap-tiap negeri di Malaysia terdapat Mahkamah Syari'ah. Mahkamah Syari'ah didirikan atas dasar Enakmen terkait Agama Islam di negeri yang 
bersangkutan. Menurut Ahmad Ibrahim dan Ahilemah Joned (2005: 333) dijelaskan bahwa:

Secara hierarki, Mahkamah Syari'ah terdiri dari Mahkamah Kadi, Mahkamah Kadi Besar dan Lembaga Rayuan. Mahkamah ini mempunyai bidang kuasa dalam kes-kes sipil dan jenayah. Bidang kuasa sipil meliputi tuntutan-tuntutan perceraian, nafkah dan tuntutan harta sepencarian serta harta pusaka. Bidang kuasa jenayah meliputi perbicaraan semua kesalahan yang diperuntukkan oleh enakmen yang berkenaan. Lazimnya kesalahan yang membawa hukuman ringan dibicarakan oleh Mahkamah Kadi, sementara kesalahan-kesalahan yang membawa hukuman yang berat dibicarakan oleh Mahkamah Kadi Besar. Rayuan daripada kedua-dua mahkamah ini akan didengar oleh Lembaga Rayuan.

Sejarah awal terbentuknya Mahkamah Syari'ah bermula dari pentadbiran Majlis Ugama Islam (MUIS), yang semula dikenal sebagai Mahkamah Qadhi. Selain Mahkamah Qadhi, di bawah MUIS ada pula Pejabat Agama Islam (semacam KUA), dan Unit Kemuftian (semacam MUI). Pemisahan Institusi Kehakiman Syari'ah (Mahkamah Syari'ah) berlaku sejak pembentukan Jabatan Kehakiman Syari'ah Negeri Sabah, tahun 1996. Pengadilan Syari’ah di Malaysia yang dikenal dengan Mahkamah Syari'ah adalah lembaga peradilan yang membicarakan, serta menjatuhkan hukuman ke atas orang Islam untuk kesalahan sipil dan kriminal agama sesuai yurisdiksi yang dialokasikan untuk Mahkamah Syari'ah.

Mahkamah Syari'ah di Malaysia memiliki tujuan dan peranan sebagai berikut:

a. Menjaga hukum Islam yang ditetapkan untuk pengadilan ini untuk menjamin setiap Muslim patuh dan tidak melanggar perintah Allah berdasarkan AlQuran dan as-Sunnah.

b. Melakukan administrasi agama Islam al-Quran dan as-Sunnah untuk menjamin kesejahteraan orang Islam.

c. Melahirkan keluarga Islam yang berpegang teguh pada ajaran Islam serta mengawasi mereka agar menjalani kehidupan sesuai syariat Islam.

d. Menyelamatkan umat Islam dari pepecahan dan keruntuhan rumah tangga.

e. Tempat referensi untuk mendapatkan konsultasi dan menyelesaikan masalah rumahtangga. 
f. Memberi bimbingan dan nasihat konseling kepada pasangan yang ingin menikah agar dapat membangun rumahtangga yang bahagia sebagaimana tuntutan agama.

g. Tempat membuat rayuan dari pihak isteri untuk mendapatkan nafkah dari suaminya yang sudah bercerai.

h. Tempat menyelesaikan masalah keluarga seperti nikah kawin, perceraian, talak, fasakh, dan sebagainya.

i. Memecahkan masalah sosial dalam masyarakat seperti judi, minum arak, riba, khalwat, dan lain-lain hal mungkar.

j. Membantu dan menyelesaikan pembagian harta pusaka dan hal-hal terkait seperti wasiat.

k. Juga bertugas sebagai penasihat jika diminta oleh pemerintah.

1. Badan yang ditunjuk oleh pemerintah yang bertanggung jawab memberi penerangan terkait dengan keagamaan, kekeluargaan dan selalu berdakwah sepanjang masa

m. Menerapkan nilai-nilai Islam agar orang Islam menerapkan sistem dan cara hidup Islam secara menyeluruh dalam kehidupan mereka.

Mahkamah Syari'ah berwenang menjalankan peraturan dan ketentuan Hukum Administrasi Agama Islam bagi setiap negeri dan daerah di Malaysia. Yurisdiksi yang diberikan adalah seperti pernikahan, perceraian, kekeluargaan serta solusi harta pusaka kecil. Mahkamah Syari'ah menjalankan tugas yang terpisah dengan Kantor Agama. Kantor Agama menjalankan pemerintahan dalam hal-hal yang bersangkutan dengan masyarakat Islam seperti urusan zakat, Baitulmal, dakwah, pendidikan, manajemen masjid dan sebagainya sesuai kuasa untuk setiap negeri tersebut di Malaysia.

Mahkamah Syari'ah di Malaysia terdiri dari Mahkamah Rendah Syari'ah, Mahkamah Tinggi Syari'ah dan Mahkamah Rayuan Syari'ah. Mahkamah Rendah Syari'ah berwenang untuk: (a) membicarakan kasus-kasus yang ditetapkan oleh enakmen negeri; (b) mendengar dan memutuskan kasus tersebut; (c) menyediakan kertas-kertas hasil dan laporan pengadilan; dan (d) membicarakan kasus di tingkat daerah, sedangkan mahkamah Tinggi Syari'ah berwenang untuk: (a) membicara- 
kan kasus-kasus yang dialokasikan kepadanya; (b) mengeluarkan perintah kasuskasus sipil dan kriminal; (c) memecahkan dan mengkonfirmasi kasus faraid; (d) mengelola kasus banding; dan (e) menyediakan jurnal pengadilan untuk diterbitkan (pada beberapa negara). Selanjutnya Mahkamah Rayuan Syari'ah, berwenang untuk: (a) mendengar kasus-kasus banding; (b) memiliki kuasa pembatalan setiap sabetan hukuman oleh Pengadilan Syari'ah; (c) mengurangi hukuman; (d) memerintah agar diadakan pembicaraan kembali atau ulang bicara; (e) menerima banding responden yang dihukum penjara atau denda tidak kurang RM 25.00 dan telah membuat banding menurut prosedur yang telah ditetapkan; dan (f) setiap banding akan didengar setidaknya oleh tiga orang panel (hakim) banding dari Panel (Hakim) Rayuan Syari'ah yang ditunjuk dan ditaulaiha oleh KDYMM Sultan (Ketua Hakim adalah Ketua Panel Rayuan Syari’ah).

Mahkamah Syari'ah memiliki yurisdiksi sebagaimana yang ditetapkan oleh Konstitusi Malaysia. Amandemen Perkara 121 (1A) Konstitusi Federal pada 1988 memberi yurisdiksi Mahkamah Syari'ah terpisah dari pengadilan sipil, menjadikan Mahkamah Syari'ah bebas dari campur tangan pengadilan biasa dan dianggap setara. Pengaturan tentang wewenang Mahkamah Syari'ah diatur dalam enakman negeri. Adapun Enakmen dan Akta Kekeluargaan Islam di Malaysia terdiri dari:

Tabel 1:

Enakmen dan Akta Kekeluargaan Islam di Malaysia

\begin{tabular}{clll}
\hline No. Negeri & Nama Akta/Enakmen & $\begin{array}{l}\text { Nomor } \\
\text { Rujukan }\end{array}$ \\
\hline 1. Johor & $\begin{array}{l}\text { Enakmen Undang-Undang Keluarga } \\
\text { Islam (Negeri Johor) 2003 (En. } \\
\text { 17/03) }\end{array}$ \\
\hline & & \\
\hline 2. & Negeri & Enakmen Undang-undang Keluarga & $7 / 1983$ \\
& Sembilan & Islam Negeri Sembilan & \\
\hline 3. & Pahang & Enakmen Undang-undang Keluarga & $3 / 2005$ \\
& & Islam Pahang & \\
\hline 4. & Perak & Enakmen Undang-undang Keluarga & $13 / 1991$ \\
& & Islam Perak & \\
\hline 5. & Perlis & Enakmen Undang-undang Keluarga & $4 / 1992$ \\
& & Islam Perlis & \\
\hline
\end{tabular}


Lanjutan Tabel 1:

\begin{tabular}{rlll}
\hline No. & Negeri & Nama Akta/Enakmen & $\begin{array}{l}\text { Nomor } \\
\text { Rujukan }\end{array}$ \\
\hline 6. & Pulau Pinang & $\begin{array}{l}\text { Enakmen Undang-undang Keluarga } \\
\text { Islam Pulau Pinang }\end{array}$ & $2 / 1985$ \\
\hline 7. & Selangor & $\begin{array}{l}\text { Enakmen Undang-undang Keluarga } \\
\text { Islam Selangor }\end{array}$ & $4 / 1984$ \\
\hline 8. & Terengganu & $\begin{array}{l}\text { Enakmen Undang-Undang } \\
\text { Pentadbiran Keluarga Islam 1985 } \\
\text { (En. 12/85) }\end{array}$ & $12 / 1985$ \\
\hline 9. & Kedah & Enakmen Keluarga Islam Kedah & $1 / 1984$ \\
\hline 10. & Kelantan & Enakmen Keluarga Islam Kelantan & $1 / 1983$ \\
\hline 11. & Melaka & Enakmen Keluarga Islam Melaka & $8 / 1983$ \\
\hline 12. & Sabah & Enakmen Keluarga Islam Sabah & $15 / 1992$ \\
\hline 13. & Sarawak & $\begin{array}{l}\text { Ordinan Undang-undang Keluarga } \\
\text { Islam Sarawak }\end{array}$ & $5 / 1991$ \\
\hline 14. & W. Persekutuan & $\begin{array}{l}\text { Akta Undang-undang Keluarga } \\
\text { Islam Wilayah Persekutuan }\end{array}$ & $\begin{array}{l}\text { (A303) 1983 } \\
\text { pindaan/(A828) }\end{array}$ \\
\hline
\end{tabular}

Sumber: Portal Rasmi E-Syari'ah.

Keberadaan dan pergulatan politik hukum Mahkamah Syari'ah di Malaysia memiliki sejarah yang panjang, sejak zaman Kesultanan Islam, Kolonial Inggris dan pasca kemerdekaan yang hingga saat ini belum selesai. Bahkan upaya penyatuan dan penyeragaman Mahkamah Syari'ah di bawah kendali pemerintahan Malaysia masih menemui jalan buntu dan mendapatkan pertentangan dari kerajaan-kerajaan negeri (negara bagian). Mahkamah Syari'ah di Malaysia masih banyak ditentukan dan bergantung kepada kebijakan politik dan hukum kerajaan negeri bersangkutan, karena sistem pemerintahan federal yang memberikan kekuasaan dan kewenangan lebih besar kepada kerajaan negeri (negara bagian) dalam mengatur negaranya, dan walaupun konstitusi Malaysia menjadikan Islam sebagai agama resmi, tetapi jika negara bagian itu pemerintahannya menjaga dan menerapkan Islam dalam kehidupan politik bernegara, maka Mahkamah Syari'ah akan maju dan berkembang dengan pesat, begitu pula sebaliknya. Pemerintahan Malaysia saat ini ingin menyeragamkan dengan menempatkan mahkamahmahkamah syari'ah yang ada di negara-negara bagian dalam kekuasaan dan kewenangan pemerintahan Malaysia di pusat seperti di Indonesia yang bermuara ke Mahkamah Agung, tetapi hirarki Mahkamah Syari'ah di Malaysia saat ini 
belum sampai ke pusat (Mahkamah Persekutuan). Peradilan tertinggi untuk mahkamah syari'ah hanya sampai pada Mahkamah Rayuan Syari'ah yang terletak di ibukota negara bagian (kerajaan negeri).

\section{Sistem peradilan Islam di Saudi Arabia}

Berdasarkan Pasal 1 Bab 1 Titah Raja No. A/90 tanggal 27 Sya'ban 1412 $\mathrm{H}$ tentang Basic Law of Goverment ditentukan bahwa kerajaan Saudi Arabia adalah sebuah negara Islam berdaulat, Agamanya Islam, Konstitusinya kitab Allah, Al Qur an al-Karim dan Sunnah Nabi SAW. Islam sebagai dasar Negara Saudi Arabia, Alqur'an dan Sunnah Rasulullah merupakan Undang Undang Dasar negara, dan syari'ah sebagai hukum dasar yang dilaksanakan oleh mahkamahmahkamah (pengadilan-pengadilan) syar'iyah dengan ulama sebagai hakim dan penasehat-penasehat.

Merujuk pada buku Muhammad Qutb, Islam the Misunderstood Religion (Islam Agama yang Disalahpahami) tampak jelas bahwa hukum Islam juga menjadi hukum yang disalahpahami. Ada beberapa isu yang menjadi sasaran kesalahpahaman orang terhadap hukum Islam dan banyak contoh yang sering dianggap sebagai kesalahpahaman oleh banyak orang. Misalnya, perbudakan, poligami, pajak bagi kafir dzimmi dan lain-lain. Selain itu, kesalahpahaman dan serangan-serangan kerap ditujukan terhadap hukum pidana Islam, bahkan ini disuarakan lebih kencang lagi.

Beberapa kesalahpahaman tersebut karena masyarakat belum benar-benar menguasai secara dalam makna dan kandungan yang terdapat dalam hukum Islam, terutama hukum pidana Islam. Bukti-bukti empiris menunjukkan bahwa pelaksanaan hukum pidana Islam di Negara Arab mampu menekan angka kejahatan sampai pada titik yang sangat rendah. Bahkan Freda Adler memasukkan Negara ini ke dalam sepuluh negara dengan predikat "Negara-negara terkecil angka kejahatannya" di banding dengan negara-negara lain di dunia (Freda Adler, Mueller dan William, 1991: 170-171)

Saat kejahatan telah menjadi sesuatu yang menakutkan, hukum Pidana Islam terbukti menjadi terapi. Dalam catatan beberapa bulan setelah berdirinya kerajaan Arab Saudi yang menegakkan syari'at Islam, perampokan yang 
memenuhi jalan-jalan di tengah padang pasir dapat dibersihkan total. Dalam kurun waktu 25 tahun tercatat hanya enam belas kali pelaksanaan hukuman potong tangan. Orang juga dapat melihat tempat-tempat penukaran uang di kota Mekah yang hanya ditutup dengan kain ketika ditinggal shalat oleh pemiliknya (Mukhlas Hasyim: 2001).

Hukum pidana Islam memenuhi syarat sebuah hukum pidana moderen. Hukum ini juga mengenal asas-asas atau prinsip-prinsip hukum pidana, baik yang sudah dikenal hukum barat maupun belum. Seperti asas lagalitas, asas tidak berlaku surut dan lain-lain. Satu hal yang jelas yaitu hukum pidana Islam berbeda dengan hukum Barat yang tidak mengakui aspek agama. Hukum ini justru erat kaitannya dengan agama sebagai jalan hidup manusia. Masih terdapat beberapa kelebihan dan keunggulan hukum pidana Islam, sehingga dengan kelebihan tersebut menjadikan banyak kalangan orang tertarik untuk memformulasikannya ke dalam sebuah aturan yang resmi dalam sebuah tata peraturan yang berlaku dalam suatu sistem pemerintahan.

Menurut Rifyal Ka'bah (2009: 31) dijelaskan bahwa peradilan Saudi Arabia terbentuk berdasarkan syari'at Islam tidak terlepas dari peran Raja Abdul Aziz bin Abdul Rahman as-Saud yang membaiat wilayah-wilayah. Peradilan Saudi Arabia dapat menjadi salah satu pilihan sistem peradilan moderen dan menarik untuk dipelajari karena beberapa hal di antaranya:

a. Saudi Arabia adalah tempat dilahirkan Nabi Muhammad SAW dan agama Islam menjadi panutan umat di seluruh dunia, tetapi negara ini mempunyai sistem pemerintahan yang berbeda dengan negara-negara muslim lainnya.

b. Negara ini tidak dapat dikategorikan sebagai negara sipil, tetapi proses penegakan hukum di negara ini dapat berjalan dengan tertib meskipun tidak menggunakan sistem civil law.

c. Saudi Arabia tidak mengenal pemisahan kekuasaan legislatif, eksekutif, dan yudikatif. Kekuasaan negara ini berjalan di bawah Raja secara harmonis dan selalu berpegang teguh pada syariat Islam.

d. Negara Saudi Arabia mengalami kemajuan atau moderenisasi tetapi mereka tetap berpegang teguh pada syariat Islam dan tetap menggunakan tradisi lama. 
Badan yudikatif Saudi Arabia disebut Dewan Tinggi Peradilan atau Supreme Council of Judiciary (SCJ) yang bertugas sebagai lembaga yang mengatur administrasi peradilan dan masalah mengenai kewenangan mengadili. Dewan tinggi peradilan ini beranggotakan 11 (sebelas) orang yang dipilih dari kalangan ulama terkemukan di Saudi Arabia. Lembaga yang mempunyai kewenangan dalam menyelesaikan persoalan hukum di Saudi Arabia yaitu Mahkamah Syar'iyah dan Lembaga Fatwa. Kedua lembaga ini memiliki kewenangan yang berbeda. Mahkamah Syari'ah mempunyai kewenangan absolut dan kewenangan relatif. Mahkamah Syari'ah memeriksa perkara pidana (jinayah) perkara perdata (muamalah), dan wilayah juridiksinya terbatas berdasarkan kompentensi relatifnya.

Hakim-hakim di Mahkamah Syari'ah dalam memeriksa suatu perkara yang tidak ditemukan dasar-dasar hukum dalam Qur'an atau Sunnah Rasulullah atau basic law of government, maka diberikan kebebasan untuk berijtihad. Ijtihad hakim baik berdasarkan pada keputusan hakim atas suatu perkara yang sebelumnya dengan sifat dan karakteristik perkara yang sama, maupun menggunakan hasil pemikiran para ulama hukum Islam klasik. Bahkan seperti penerapan hukum Islam di dunia Islam lainnya, keputusan hakim mahkamah syar'iyah sebagai yurisprudensi bagi hakim dalam menghadapi perkara yang mempunyai sifat dan krakteristik yang sama.

Lembaga Fatwa berfungsi untuk memberikan keputusan hukum atas suatu persoalan yang menyangkut dengan kemaslahatan umum, baik menyangkut dengan masalah hak kewargaan negara maupun persoalan politik baik dalam negeri maupun luar negeri. Keputusan hukum Lembaga Fatwa bersifat mengikat untuk dan bagi seluruh warga negara Arab Saudi.

Oyo Sunaryo Mukhlas (2011: 111-112), mengatakan bahwa berdasarkan ketentuan kerajaan Saudi Arabia tertanggal 06 Safar 1346 Hijriyah atau 12 Agustus 1927 Masehi, semua lembaga peradilan yang sebelumnya dihapus dan pengadilan Saudi Arabia terdiri atas 3 tingkatan, sebagai berikut:

a. Al Mahakim Al Musta’jilah/Mahakim Juz'iyah, yaitu peradilan segera. Lembaga peradilan ini merupakan peradilan tingkat pertama, yang bertugas menyelesaikan perkara-perkara yang mendesak, baik dalam bidang perdata 
maupun pidana. Bidang pidana menyangkut kejahatan yang menimbulkan luka, berkaitan dengan ta'zir dan hudud yang ringan. Tidak berlaku pada hukuman potong tangan dan hukuman mati (qisas). Bidang perdata menyangkut masalah uang yang tidak lebih dari 300 riyal, tidak berlaku putusan yang yang menyalahi agama dan ijma' (konsensus ahli hukum Islam). Perangkat penegak hukum yang bertugas pada pengadilan pertama ini adalah hakim tunggal.

b. Al Mahakim Asy-syar'iyyah, yaitu peradilan syari'ah. Peradilan ini berwenang menangani perkara pidana berat, seperti hukuman potong tangan dan hukuman mati. Berwenang pula menyelesaikan perkara al ahwal al syakhsiyah, yang mencangkup: nikah, talak, rujuk, wasiat, dan al mal yang nilainya di atas 300 riyal. Perangkat hukum yang bertugas pada pengadilan banding ini terdiri atas 3 (tiga) orang hakim (majelis), seorang ketua, dua orang anggota. Setiap keputusan diberikan berdasarkan suara terbanyak, sedangkan dalam perkara pidana pidana berat, seperti hukuman potong tangan dan hukuman mati dilakukan melalui sidang pleno peradilan.

c. Hay'ah Muraqabah al-Qadha'iyyah, yaitu Badan Pengawas Peradilan. Badan pengawas peradilan ini dinamakan dengan Peradilan Syari'at Agung. Tugas dan wewenang lembaga ini, antara lain:

1) mengadili perkara-perkara banding atas putusan peradilan yang ada di bawahnya;

2) mengendalikan administrasi dan mengawasi pengadilan;

3) menerbitkan fatwa yang dimintakan kepadanya;

4) mengawasi lembaga pendidikan dan kurikulum pendidikan; dan

5) supervisi terhadap lembaga-lembaga amar ma'ruf nahi mungkar

Secara umum, lembaga peradilan di Saudi Arabia menganut sebuah sistem hukum ganda, yang terdiri atas 2 (dua) jenis, yaitu pertama, peradilan berdiri sendiri yang bersifat otonomi, tetapi tidak bertentangan dengan syari'at, kedua peradilan syar'iyah (peradilan syari'at Islam) yang sepenuhnya berdasar syari'at. Peradilan berdiri sendiri yaitu peradilan yang bersifat administratif. Peradilan ini tidak secara khusus berdasarkan Syari'at Islam, tetapi dirancang agar sesuai dengan prinsip-prinsip syari'at dengan memperhatikan dan mengambil jiwa syari'at secara umum (Rifyal Ka'bah, 2009: 37-40).

Menurut Rifyal Ka'bah (2009: 40), dikatakan bahwa Peradilan Syari'ah (Peradilan Syari'at Islam), yaitu peradilan yang sepenuhnya berdasarkan Syari'at. Peradilan Syari'ah, terdiri atas 4 (empat) tingkatan peradilan, yaitu:

a. Majelis al-Qadha al-A'la (Mahkamah Agung), yang secara administratif, mahkamah ini berwenang mengangkat, mengatur kenaikan pangkat, pemindahan dan pengaturan cuti para hakim, sedangkan secara yuridis, berwenang meninjau ulang putusan-putusan peradilan yang lebih rendah 
tingkatannya, seperti dalam putusan hukuman mati, potong tangan dan hukum rajam.

b. Mahkamah al-Tamyiz (Peradilan Tingkat Banding), yang berwenang untuk meninjau ulang segala putusan perdata dan pidana yang diputuskan oleh hakim dalam peradilan yang tingkatannya lebih rendah. Di dalam mahkamah ini, putusan diambil secara kolektif oleh majelis hakim (tiga orang hakim), kecuali dalam hal hukuman mati, potong tangan, dan rajam yang harus diputuskan oleh 5 (lima) orang hakim.

c. Al-Mahakim al-'Ammah (Pengadilan Biasa), yang berwenang mengadili segala macam perkara. Putusan ini diambil oleh seorang hakim, kecuali dalam perkara pembunuhan, zina (hukum rajam), dan pencurian (potong tangan) yang putusannya dilakukan oleh 3 (tiga) orang hakim.

d. Al-Mahakim al-Juz'iyah (Pengadilan Segera), yang berwenang mengadili perkara-perkara ringan, seperti perkara-perkara yang mendapat hukum ta'zir, hukuman bagi pemabuk minuman keras, dan perkara utang piutang yang tidak lebih dari 8.000 riyal. Perkara ini dipandang ringan dan dapat diselesaikan dengan segera

Dijelaskan lebih lanjut oleh Rifyal Ka'bah (2009: 41), bahwa Raja Abdullah bin 'Abd al-'Aziz pada tanggal 1 Oktober 2007 telah menerbitkan Royal Order (Titah Raja) tentang pembaharuan peradilan. Berdasarkan aturan baru ini, maka hirarki Pengadilan Syari'at menjadi tiga tingkat, yaitu:

a. Pengadilan Tinggi sebagai Mahkamah Agung.

b. Pengadilan Tingkat Banding yang terdiri dari:

1) Pengadilan Perdata;

2) Pengadilan Pidana;

3) Pengadilan Hukum Keluarga;

4) Pengadilan Perdagangan; dan

5) Pengadilan Perburuhan.

c. Ketiga adalah Pengadilan Tingkat Pertama yang terdiri dari:

1) Pengadilan Umum;

2) Pengadilan Pidana;

3) Pengadilan Hukum Keluarga;

4) Pengadilan Perdagangan; dan

5) Pengadilan Perburuhan.

Sesuai aturan baru Pengadilan Diwan al-Mazhalim berubah menjadi

Badan Peradilan Administratif yang mempunyai hirarki mirip dengan hirarki Pengadilan Syari'at (Rifyal Ka'bah, 2009: 41), yang terdiri dari:

a. Pengadilan Tinggi Administratif.

b. Pengadilan Banding Administrasi, terdiri dari:

1) Bidang Pendisiplinan;

2) Bidang Administratif;

3) Bidang Subsider; dan 
4) Bidang Spesialisasi yang lain.

c. Pengadilan Tingkat Pertama Administratif, terdiri dari :

1) Bidang Pendisiplinan;

2) Bidang Administratif;

3) Bidang Subsider; dan

4) Bidang Spesialisasi yang lain.

\section{Simpulan dan Saran}

\section{Simpulan}

Berdasarkan penjelasan di atas, dapat disimpulkan bahwa terdapat perbedaan Mahkamah Syari'ah (Peradilan Islam) antara Malaysia dan Saudi Arabia, yaitu:

a. Mahkamah Syari'ah di Malaysia ditetapkan dengan Konstitusi Federal Malaysia, sedangkan di Saudi Arabia ditetapkan dengan undang-undang.

b. Pelaksanaan wewenang Mahkamah Syari'ah di Malaysia berdasarkan hukum Islam yang diatur dalam enakmen negeri meliputi muamalah dan jinayah, sedangkan di Saudi Arabia, pelaksanaan wewenangnya berdasarkan hukum Islam yang terdapat dalam Al Qur an dan Sunnah yang meliputi perdata, pidana, hukum keluarga, dan perdagangan.

c. Upaya hukum di Malaysia hanya sampai tingkat banding pada Mahkamah Syari'ah Negara Bagian (tidak sampai ke negara federal), sedangkan di Saudi Arabia, upaya hukum sampai pada tingkat kasasi ke Mahkamah Agung.

\section{Saran}

Mahkamah Syari'ah di Aceh hampir sama dengan Mahkamah Syari'ah di Malaysia, terdiri dari Mahkamah Rayuan Syari'ah, Mahkamah Tinggi Syari'ah dan Mahkamah Rendah Syari'ah, yang memiliki kekuasaan dan kewenangan yang hampir sama. Terkait dengan hal ini, perlu kiranya Konstitusi Negara Republik Indonesia mempertegas kedudukan Mahkamah Syari'ah sebagai bagian dari sistem peradilan di Indonesia, khususnya untuk perkara-perkara yang terkait dengan ajaran Islam. 


\section{DAFTAR PUSTAKA}

\section{Buku:}

Abdul Rahman Haji Abdullah. 1997. Pemikiran Islam di Malaysia Sejarah dan Pemikiran. Cetakan I. Jakarta: Gema Insani Press.

Ahmad Ibrahim dan Ahilemah Joned. 2005. Sistem Undang-undang di Malaysia. Selangor Darul Ehsan: Dawarna Sdn. Bhd.

Ahmad Mohamed Ibrahim. 1985. Sistem Undang-undang di Malaysia. Kuala Lumpur: Kementerian Pelajaran Malaysia.

-------. 1972. Moeslem Doctrine and Human Rights Islam. Bairut: Dar al-Kitab al-Lubnany.

Bambang Sunggono. 1998. Metodologi Penelitian Hukum. Cetakan Kedua. Jakarta: RajaGrafindo Persada.

Basiq Djalil. 2006. Peradilan Agama di Indonesia: Gemuruhnya Politik Hukum (Hukum Islam, Hukum Barat, Hukum Adat) dalam Rentang Sejarah Bersama Pasang Surut Lembaga Peradilan Agama Hingga Lahirnya Peradilan Syari'at Islam Aceh. Jakarta: Kencana.

Basiq Djalil. 2012. Peradilan Islam. Jakarta: Amzah.

Bernard Arief Sidharta. 2011. "Penelitian Hukum Normatif: Analisis Penelitian Filosofikal dan Dogmatikal" dalam Sulistyowati Irianto dan Shidarta (Editor). Metode Penelitian Hukum Konstelasi dan Refleksi. Cetakan Kedua. Jakarta: Yayasan Pustaka Obor Indonesia.

Esposito, John L dan John O. Volt. 1999. Islam and Democracy. Diterjemahkan oleh Rahman Astuti dengan judul Demokrasi di Negara-negara Muslim Problem dan Prospek. Cetakan I. Bandung: Mizan.

Hasbi Ash-Shiddieqy. 1994. Peradilan dan Hukum Acara Islam. Yogyakarta: Ma'arif.

Jayum A. Jawam. 2006. Malaysian Politics and Government. Selangor Darul Ehsan: Karisma Production Sdn. Bhd.

Mohd. Saleh Abbas. 2006. Prinsip Perlembagaan dan Pemerintahan di Malaysia. Selangor Darul Ehsan: Dawarna Sdn. Bhd.

Mueller, Freda Adler dan William. 1991. Criminology. New York: Mc Graw Hill.

Muhammad Tahir Azhari. 1992. Negara Hukum; Suatu Studi tentang Prinsipprinsipnya Dilihat dari Segi Hukum Islam: Implementasinya pada Periode Negara Madinah dDan Masa Kini. Jakarta: Bulan Bintang.

Oyo Sunaryo Mukhlas. 2011. Perkembangan Peradilan Islam dari Kahin di Jazirah Arab ke Peradilan Agama di Indonesia. Bogor: Ghalia Indonesia. 
Rifyal Ka'bah. 2010. Peradilan Islam Kontemporer: Saudi Arabia, Mesir, Sudan, Pakistan, Malaysia dan Indonesia. Jakarta: Universitas Yarsi.

Rochmat Soemitro. 1976. Masalah Peradilan Administrasi dalam Hukum Pajak di Indonesia. Bandung: Eresco.

Ronny Hanitijo Soemitro. 1990. Metodologi Penelitian Hukum dan Jurumetri. Jakarta: Ghalia Indonesia. 1990.

Sjahran Basah. 1986. Hukum Tata Negara Perbandingan. Bandung: Alumni.

Soerjono Soekanto dan Sri Mamudji. 2001. Penelitian Hukum Normatif. Jakarta: RajaGrafindo Persada.

Soerjono Soekanto. 1986. Pengantar Penelitian Hukum. Cetakan Ketiga. Jakarta: UI-Press.

Sudirman Tebba. 1993. Perkembangan Mutakhir Hukum Islam di Asia Tenggara Studi Kasus Hukum Keluarga dan Pengkodifikasiannya. Cetakan I. Bandung: Teraju Mizan.

Undang-undang Malaysia. 2006. Perlembagaan dan Undang-undang AM. Buku Panduan untuk Peperiksaan Am Kerajaan. Kuala Lumpur: MDC Publishers Sdn. Bhd.

\section{Jurnal/Makalah/Ensiklopedi:}

Bagir Manan. 1998. "Memberdayakan Kekuasaan Kehakiman”. Makalah. Disampaikan pada Seminar Nasional Upaya Meningkatkan Fungsi dan Peranan Mahkamah Agung Republik Indonesia dalam Mewujudkan Kekuasaan Kehakiman yang Merdeka Berdasarkan Pancasila. Bandung: Bappenas-Fakultas Hukum Unpad.

. 1999. "Penelitian di Bidang Hukum". Jurnal Hukum Puslitbangkum. Nomor 1. Bandung: Pusat Penelitian Perkembangan Hukum Unpad.

Fahim Abdullah bin Abdul Rahman. 1991. "Mahkamah Syari'ah Islam dan Permasalahannya". Mimbar Hukum. Nomor. 38 Tahun IX. Jakarta: AlHikmah.

Mukhlas Hasyim. 2001. "Aspek Perlindungan HAM dalam Hukum Pidana Islam”. Makalah. Disampaikan pada Diskusi Menyibak Aspek Perlindungan HAM dalam Hukum Pidana Islam. Yogyakarta; Fakultas Hukum Universitas Islam Indonesia.

Tengku Erwinsyahbana. 2017. "Pertanggungjawaban Yuridis Direksi terhadap Risiko Kerugian Keuangan Daerah pada Badan Usaha Milik Daerah”. De Lega Lata Jurnal Ilmu Hukum. Volume 2. Nomor 1. Januari-Juni. Medan: Fakultas Hukum Universitas Muhammadiyah Sumatera Utara. 


\section{Internet:}

Anonim, "Peradilan pada Kerajaan Saudi Arabia", http://scarmakalah.blogspot. co.id., diakses tanggal 25 Juni 2017.

Shoim Najwa. "Peradilan dalam Islam". http://shoimnj.blogspot.co.id/2011/07/ peradilan-dalam-islam.html, diakses tanggal 20 Juni 2017. 


\section{BIODATA PENULIS}

$\begin{array}{ll}\text { Nama } & : \text { Dr. Yusrizal, S.H., M.H } \\ \text { Pekerjaan } & : \text { Dosen Fakultas Hukum Universitas Malikussaleh } \\ \text { Jabatan } & : \text { Lektor } \\ \text { Nomor HP } & : 085220081739 \\ \text { E-mail } & : \text { yusrizal_unimal@yahoo.co.id } \\ \text { Alamat Kantor } & : \text { Komplek Kampus Bukit Indah (BI), Jalan Jawa, Padang Sakti, } \\ & \end{array}$

